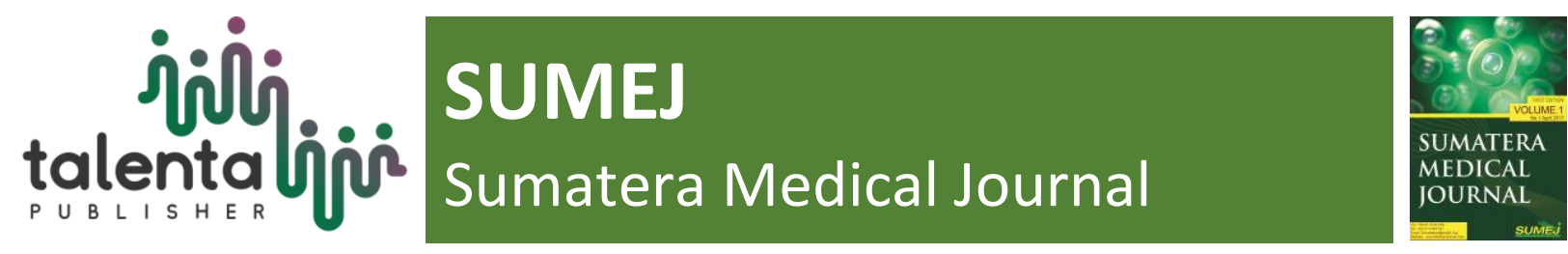

\title{
Urinary Tract Infection Bacterial at RSUP H. Adam Malik Medan in 2019: an Overview Study
}

\author{
Teguh Firdaus ${ }^{1}$, Rina Yunita ${ }^{2}$ \\ ${ }^{1}$ Faculty of Medicine, Universitas Sumatera Utara, Medan, North Sumatera, Indonesia \\ ${ }^{2}$ Department of Microbiology, Universitas Sumatera Utara, Medan, North Sumatera, Indonesia
}

\begin{abstract}
Urinary Tract Infection (UTI) is the second-largest infection after respiratory tract infection (WHO, 2013). The prevalence of UTI in Indonesia is relatively high. UTI originated from the invasion and proliferation of microorganisms into the urinary tract in meaningful quantities. Gram-negative bacteria are mostly the cause of UTI including E. coli, Klebsiella sp, Enterobacter sp, and Proteus sp. Patients with UTI with inadequate treatment can experience complications e.g., acute renal failure and urosepsis. This study aims to find out the profile of bacteria that cause UTI at RSUP H. Adam Malik Medan in 2019. This descriptive study is using a non-analytical retrospective approach conducted to secondary data from urinary culture examination at RSUP H. Adam Malik Medan. Data were analyzed using the SPSS 24. Gram-negative bacteria results of $72.7 \%$ with E. coli postulated as the most common etiology (33,3\%) and gram-positive bacteria results of 27.3\%, dominated by Enterococcus faecalis (16.3\%). The sensitivity study exhibited various results e.g., 100\%, 98.2\%, and 97.0\% in E. coli for Tigecycline, Meropenem, and Amikacin respectively. Enterococcus faecalis also posed a similar results regarding its sensitivity result to different antibiotics. Gram-negative bacteria are the most common bacterial etiology of UTI, specifically E. coli with comparable sensitivity results
\end{abstract}

Keyword: Antibiotics, Bacteria, Hospital, Sensitivity, UTI

Received date month year. | Revised date month year | Accepted date month year

${ }^{*}$ Corresponding author at: Faculty of Medicine, Universitas Sumatera Utara, Medan, North Sumatera

E-mail address: teguhfirdaus28@gmail.com 


\section{Introduction}

Urinary Tract Infection (UTI) is an inflammatory reaction of the urothelium due to the entry of microorganisms into the urinary tract. UTI can affect any age from asymptomatic to severe symptoms. Clinical epidemiology research data reports almost $25-35 \%$ of all adult women experience UTI during their lifetime. In UTI, microorganisms can multiply in the urinary tract, which under normal circumstances does not contain bacteria, viruses, or other microorganisms [1].

According to the World Health Organization (WHO), UTI is the second most common infectious disease in the body after respiratory tract infections and as many as 8.3 million cases are reported per year. This infection is also more common in women than in men. Indonesia is the fourth largest country in the world after China, India, and the United States [2]. Meanwhile, in Indonesia, 222 million people suffer from UTIs and the prevalence is still quite high. According to the estimates of the Ministry of Health of the Republic of Indonesia, the number of people with UTI in Indonesia is $90-100$ cases per 100,000 inhabitants per year or about 180,000 new cases per year [3].

In Indonesia, UTI is a relatively frequent disease at all ages ranging from infants to the elderly. As we get older, the incidence of UTI is more common in women than in men because the female urethra is shorter than that of men [4]. Infections usually enter the urinary tract through the urethra, but blood-borne infections can deposit in the kidneys. UTI is diagnosed if there are more than 100,000 bacteria of the same species per milliliter of urine. Urine screening detects asymptomatic bacteriuria in approximately $5 \%$ of women. About $30 \%$ develop into symptomatic in one year [5].

UTI is caused by bacteria, but fungi and viruses can also be the cause. The bacteria that often cause UTI is Escherichia coli, an organism that can be found in the anus. In addition to Escherichia coli bacteria that can cause UTI are Proteus sp, Klebsiella sp, Pseudomonas sp, Enterococcus sp, and Staphylococcus sp [6].

Treatment of UTI requires supportive therapy and adequate antibiotics. Some of the antibiotics recommended by the Indonesian Urological Association as a therapy include fluoroquinolone, a combination of aminopenicillin with beta-lactam inhibitors, cephalosporins, aminoglycosides, and carbapenem. But the problem of bacterial resistance to antibiotic use is one of the growing problems around the world [7].

\section{Method}

This research is a descriptive observational study with a retrospective non-analytical approach. This study was conducted to create an overview or description of the bacteria that cause urinary tract infections objectively by looking back. 
This research was conducted in the clinical microbiology unit of RSUP H. Adam Malik Medan from July 2020 to October 2020. The population in this study was all urinary tract infection patients who performed urine culture at the Clinical Microbiology Laboratory of RSUP H. Adam Malik Medan in 2019. Sampling techniques in this study is total sampling, meaning that the samples taken are the entire total population that has met the criteria of inclusion and exclusion of research.

The inclusion criteria in this study are urinary tract infection patients with complete data on microorganism culture examination at RSUP H. Adam Malik Medan Microbiology Laboratory in 2019. The exclusion criteria in this study were patients with urinary tract infections due to fungal infections and urine culture results with insignificant bacterial growth.

Data is processed through several stages, namely Editing, Coding, Entering, Cleaning, and Saving. The data obtained is then presented descriptively in the form of narration and proportion distribution tables. Data obtained from this study is processed and analyzed using SPSS software (Statistic Package for Social Science)

\section{Result and Discussion}

In this study, from the secondary data collection of microbiology laboratory RSUP H. Adam Malik Medan obtained the total population of the study was 553 patients. The sample that has met the researchers inclusion criteria is as many as 520 patients.

Table 1. Description of Bacterial Samples by Specimen Type

\begin{tabular}{ccccc}
\hline Specimen Type & Gram Negative & Percentage(\%) & Gram Positive & Percentage(\%) \\
\hline Midstream Urine & 212 & 73.4 & 77 & 26.6 \\
Catheter Urine & 164 & 71.6 & 65 & 28.4 \\
Suprapubic Urine & 2 & 100 & 0 & 0 \\
\hline Total & $\mathbf{3 7 8}$ & $\mathbf{7 2 . 7}$ & $\mathbf{1 4 2}$ & $\mathbf{2 7 . 3}$ \\
\hline
\end{tabular}

On table 1, it can be seen that the type of urine specimen of the midstream urine was found gram negative bacteria as much as $212(73.4 \%)$ and 77 gram-positive bacteria (26.6\%). Then in this type of catheter urine specimens found gram-negative bacteria as much as $164(71.6 \%)$ and 65 gram-positive bacteria (28.4\%). While suprapubic urine specimens found gram-negative bacteria as many as $2(100 \%)$ and no gram-positive bacteria were found in this specimen.

The results of this study are in accordance with previous research that the most common type of bacteria causing UTI is gram-negative bacterial types whereas gram-positive bacteria are less common in UTI patients [4]. 
Table 2. Description of Bacterial Samples by Bacterial Name

\begin{tabular}{|c|c|c|c|}
\hline Microorganisms & Species & Frequency & Percentage $(\%)$ \\
\hline \multirow[t]{27}{*}{ Gram Negative Bacteria } & Achromobacter denitrificans & 1 & 0.2 \\
\hline & Acinetobacter baumanii & 31 & 6 \\
\hline & Acinetobacter haemolyticus & 1 & 0.2 \\
\hline & Acinetobacter lwoffii & 3 & 0.6 \\
\hline & Aeromonas hydrophila/caviae & 6 & 1.2 \\
\hline & Aeromonas sobria & 1 & 0.2 \\
\hline & Burkholderia cepacia & 10 & 1.9 \\
\hline & Citrobacter freundii & 8 & 1.5 \\
\hline & Citrobacter koseri & 1 & 0.2 \\
\hline & Cronobacter sakazakii & 1 & 0.2 \\
\hline & Enterobacter aerogenes & 1 & 0.2 \\
\hline & Enterobacter cloacae & 14 & 2.7 \\
\hline & Escherichia coli & 173 & 33.3 \\
\hline & Klebsiella oxytoca & 3 & 0.6 \\
\hline & Klebsiella pneumoniae & 64 & 12.3 \\
\hline & Morganella morganii & 3 & 0.6 \\
\hline & Pantoea spp & 2 & 0.4 \\
\hline & Proteus mirabilis & 8 & 1.5 \\
\hline & Providencia rettgeri & 1 & 0.2 \\
\hline & Pseudomonas aeruginosa & 31 & 6 \\
\hline & Pseudomonas fluorescens & 1 & 0.2 \\
\hline & Pseudomonas putida & 7 & 1.3 \\
\hline & Pseudomonas stutzeri & 3 & 0.6 \\
\hline & Raoultella ornithinolytica & 1 & 0.2 \\
\hline & Salmonella spp & 1 & 0.2 \\
\hline & Serratia fonticola & 1 & 0.2 \\
\hline & Serratia plymuthica & 1 & 0.2 \\
\hline \multirow[t]{17}{*}{ Gram Positive Bacteria } & Enterococcus casseliflavus & 1 & 0.2 \\
\hline & Enterococcus faecalis & 85 & 16.3 \\
\hline & Enterococcus faecium & 25 & 4.8 \\
\hline & Enterococcus gallinarum & 1 & 0.2 \\
\hline & Kocuria kristinae & 1 & 0.2 \\
\hline & Kocuria rhizophila & 1 & 0.2 \\
\hline & Kocuria rosea & 1 & 0.2 \\
\hline & Lactococcus garvieae & 1 & 0.2 \\
\hline & Micrococcus luteus & 1 & 0.2 \\
\hline & Staphylococcus aureus & 5 & 1 \\
\hline & Staphylococcus haemolyticus & 10 & 1.9 \\
\hline & Staphylococcus sciuri & 3 & 0.6 \\
\hline & Staphylococcus warneri & 1 & 0.2 \\
\hline & Streptococcus agalactiae & 2 & 0.4 \\
\hline & Streptococcus mitis/oralis & 1 & 0.2 \\
\hline & Streptococcus sobrinus & 1 & 0.2 \\
\hline & Streptococcus thoraltensis & 2 & 0.4 \\
\hline Total & & 520 & 100 \\
\hline
\end{tabular}


On table 2, it can be seen that the bacteria that cause UTI is Escherichia coli which is 173

(33.3\%). Then followed Enterococcus faecalis as much as 85 (16.3\%), Klebsiella pneumoniae as much as 64 (12.3\%), Acinetobacter baumanii as much as 31 (6\%), Pseudomonas aeruginosa as much as 31 (6\%), Enterococcus faecium as much as 25 (4.8\%), Enterobacter cloacae as much as 14 (2.7\%), Burkholderia cepacia as much as 10 (1.9\%), Staphylococcus haemolyticus as much as $10(1.9 \%)$, and so on.

The results of this study correspond to previous research that the most common bacteria causing UTI are Escherichia coli [8]. It is also the main pathogen that causes UTI and is the cause of about $90 \%$ of UTI in young women [9]. Other bacteria that often cause UTI are Klebsiella pneumoniae, Pseudomonas aeruginosa, Enterobacter sp., and Enterococcus sp. [8].

Table 3. Patterns of Bacterial Sensitivity to Antibiotics

\begin{tabular}{|c|c|c|c|c|c|c|c|c|c|c|c|c|c|c|c|c|c|}
\hline \multirow[t]{2}{*}{ Organisms } & \multirow[t]{2}{*}{$(\mathrm{N})$} & \multicolumn{16}{|c|}{ Percentage of Bacterial Sensitivity to Antibiotics } \\
\hline & & AMP & AMK & ATM & CAZ & CIP & CRO & CFZ & ETP & CFP & NIT & GTM & MEM & SAM & SXT & TGC & TZP \\
\hline $\begin{array}{l}\text { Escherichia } \\
\text { coli }\end{array}$ & 164 & 3.7 & 97 & 18.9 & 29.9 & 10.4 & 14.6 & 0 & 92.7 & 35.1 & 75.6 & 62.2 & 98.2 & 12.8 & 29.3 & 100 & 65.9 \\
\hline $\begin{array}{l}\text { Enterococcus } \\
\text { faecalis }\end{array}$ & 79 & 87.3 & & & & 8.9 & & & & & 91.1 & 7.6 & & 87.3 & & 100 & \\
\hline $\begin{array}{l}\text { Klebsiella } \\
\text { pneumoniae }\end{array}$ & 62 & 0 & 91.9 & 11.3 & 12.9 & 12.9 & 11.3 & 0 & 85.5 & 36.5 & 22.6 & 35.5 & 88.7 & 9.7 & 29 & 82.3 & 33.9 \\
\hline $\begin{array}{l}\text { Acinetobacter } \\
\text { baumanii }\end{array}$ & 31 & & 71 & & 12.9 & 16.1 & 0 & 0 & & 12.9 & & 19.4 & 41.9 & 32.3 & 45.2 & 83.9 & 16.1 \\
\hline $\begin{array}{l}\text { Pseudomonas } \\
\text { aeruginosa }\end{array}$ & 31 & & 86.7 & 50 & 66.7 & 73.3 & & 0 & & 73.3 & & 76.7 & 83.3 & & & 0 & 66.7 \\
\hline $\begin{array}{l}\text { Enterococcus } \\
\text { faecium }\end{array}$ & 23 & 0 & & & & 13 & & & & & 13 & 13 & & 0 & & 100 & \\
\hline
\end{tabular}

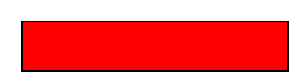

$<40 \%$ sensitive

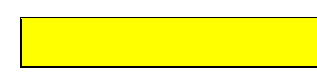

$40-70 \%$ sensitive

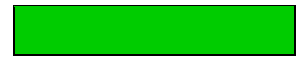

$>70 \%$ sensitive

Description:
AMP = Ampicillin
AMK = Amikacin
ATM = Aztreonam
CAZ = Ceftazidime
CIP = Ciprofloxacin
CFZ = Cefazolin
CFP = Cefepime
NIT = Nitrofurantoin
GTM = Gentamicin
MEM = Meropenem
SAM = Ampicillin/sulbactam
SXT = Trimethoprim/sulfamethoxazole
TGC = Tigecycline
$\mathrm{TZP}=$ Piperacillin/tazobactam 
On table 3, it can be seen that Escherichia coli is still sensitive to Amikacin, Ertapenem, Nitrofurantoin, Meropenem, Tigecycline. Enterococcus faecalis is sensitive to Ampicillin, Nitrofurantoin, Ampicillin/sulbactam, Tigecycline. Klebsiella pneumoniae is sensitive to Amikacin, Ertapenem, Meropenem, Tigecycline. Acinetobacter baumanii is sensitive to Amikacin and Tigecycline. Pseudomonas aeruginosa is sensitive to Amikacin, Ciprofloxacin, Cefepime, Gentamicin, Meropenem. And Enterococcus faecium is sensitive to Tigecycline.

\section{Conclusion}

From the results of this study, it can be concluded that all types of specimens found gramnegative bacteria that most often cause UTI. The most common gram-negative bacteria are Escherichia coli, while the most common gram-positive bacteria are Enterococcus faecalis. Then will be conducted a pattern test sensitivity to 6 bacteria with the highest frequency. In the sensitivity pattern test, it was found that Escherichia coli is still sensitive to Amikacin, Ertapenem, Nitrofurantoin, Meropenem, Tigecycline. Enterococcus faecalis is sensitive to Ampicillin, Nitrofurantoin, Ampicillin/sulbactam, Tigecycline. Klebsiella pneumoniae is sensitive to Amikacin, Ertapenem, Meropenem, Tigecycline. Acinetobacter baumanii is sensitive to Amikacin and Tigecycline. Pseudomonas aeruginosa is sensitive to Amikacin, Ciprofloxacin, Cefepime, Gentamicin, Meropenem. And Enterococcus faecium is sensitive to Tigecycline.

\section{REFERENCES}

[1] Kumala S., Raisa N., Rahayu L., and Kiranasari A., 2009, Uji Kepekaan Bakteri yang Diisolasi dari Urin Penderita Infeksi Saluran Kemih (ISK) terhadap Beberapa Antibiotika pada Periode Maret-Juni 2008, Majalah Ilmu Kefarmasian, 6 (2), 52.

[2] World Health Organization (WHO). 2013. Kesehatan Reproduksi Wanita Infeksi Saluran kemih (ISK). Salemba Medika. Jakarta.

[3] Departemen Kesehatan RI 2014, Waspada Infeksi Saluran Kemih: http://www.depkes.go.id/index.php/wasada+infeksi+saluran+kemih/.

[4] Purnomo, B. B. (2014). Dasar-dasar urologi. Edisi Ketiga. Malang: penerbit CV Sagung seto.

[5] Callaghan. 2009. At a Glance Sistem Ginjal. Edisi 2. Jakarta: Erlangga.

[6] Nuari, N. A., \& Widayati, D. (2017). Gangguan pada Sistem Perkemihan dan Penatalaksanaan Keperawatan. Yogyakarta: Deepublisher.

[7] Ikatan Ahli urologi Indonesia (IAUI), 2015, Guideline Penatalaksanaan Infeksi Saluran Kemih dan Genitalia Pria 2015 edisi 2, Ikatan Ahli Urologi Indonesia, Surabaya, 3.

[8] Sukandar, E. 2014. Infeksi Saluran Kemih Pasien Dewasa, dalam :. Setiati S., Alwi I., Sudoyo AW., dkk (editors) 2014, Buku Ajar Ilmu Penyakit Dalam, Edisi VI, Pusat 
Penerbitan Departemen Ilmu Penyakit Dalam Fakultas Universitas Indonesia, Jakarta. Hal: 2129-35.

[9] Brooks, G.F., Carroll, K.C., Butel, J.S., Morse S.A., Mietzner, T. 2014, Mikrobiologi Kedokteran Jawetz, Melnick, \& Adelberg. Edisi 25, Penerbit buku kedokteran EGC, Jakarta. 